\title{
Hak Masyarakat Adat (Indigenous Peoples) atas Sumber Daya Alam: Perspektif Hukum Internasional
}

\author{
Muazzin'20
}

\begin{abstract}
Abstrak
Selama dekade terakhir, hukum internasional telah berkembang lebih baik dengan mempertimbangkan hak masyarakat adat atas sumber daya alam yang kemudian memengaruhi hukum berbagai negara. Meskipun demikian, dalam praktiknya, hak masyarakat adat atas sumber daya alam tidak selalu dijamin dan ditegakkan. Selain itu, hak masyarakat adat tersebut kurang mendapatkan pengakuan hukum formal meskipun dalam beberapa tahun terakhir beberapa negara telah mengesahkan undang-undang untuk melindungi hak masyarakat adat atas sumber daya alam. Artikel ini berusaha untuk menganalisis kerangka hukum internasional yang memberikan perlindungan secara memadai terhadap isu-isu tentang hak masyarakat adat atas sumber daya alam. Konvensi ILO 169 telah menetapkan beberapa hak masyarakat adat yang penting, seperti free dan informed consent, consultation, dan compensation. Ketentuan konvensi tentang hak atas sumber daya alam memiliki pengaruh terhadap berbagai negara dalam penyusunan instrumen lainnya. Konvensi juga digunakan sebagai referensi dalam kasus hukum domestik, misalnya di Bolivia, Argentina, Venezuela, dan pengadilan regional. The United Nations Declaration on the Rights of Indigenous Peoples (UNDRIP) merupakan dokumen penting bagi pengakuan dan perlindungan hak-hak masyarakat adat di tingkat internasional. Deklarasi ini mengakui hak-hak kolektif, termasuk the right to self-determination dan the right to cultural heritage and intellectual property. Referensi tentang hak atas tanah dapat ditemukan di seluruh deklarasi. Pasal 26 merupakan salah satu ketentuan utama. Ketentuan ini memiliki visi yang jauh ke depan, terutama pengakuan bahwa masyarakat adat memiliki hak atas tanah yang mereka miliki secara tradisional dan menguasai sumber daya yang mereka miliki. Berdasarkan Pasal 32, negara berkewajiban menerapkan the free, prior and informed consent dari masyarakat adat sebelum memberikan persetujuan proyek-proyek yang dapat memengaruhi tanah mereka.
\end{abstract}

Kata kunci: hak atas sumber daya alam, hak masyarakat adat, hukum internasional, Konvensi ILO 169, sumber daya alam.

\section{The Rights of Indigeneous People over Natural Resources: International Law Perspectives}

\begin{abstract}
Over the past decade, international law has evolved so as to better take into consideration indigenous peoples' natural resources rights and has influenced in many ways the law of

20 Dosen Fakultas Hukum Universitas Syiah Kuala Aceh, Jalan T. Nyak Arief Darussalam, Banda Aceh, muaz_hukum@yahoo.co.id, S.H. (Universitas Syiah Kuala Aceh), M.H. (Universitas Padjadjaran).
\end{abstract}


numerous states. However, in practice, indigenous peoples' natural resources rights are not always guaranteed and enforced. Furthermore, most of the indigenous peoples lack formal legal recognition of their natural resources rights, although in recent years some states have adopted legislation to secure indigenous peoples' natural resources rights. This article seeks to analyze whether within the framework of international law, a sufficient protection to indigenous peoples regarding natural resources rights issues has been provided. ILO Convention 169 entrenches important indigenous peoples' rights such as free and informed consent, consultation and compensation. Its provisions on natural resources rights have had an influence on states and on the drafting of other instruments. The Convention has also been used as a point of reference in domestic case law in regional courts (for example in Bolivia, Argentina, and Venezuela). The United Nations Declaration on the Rights of Indigenous Peoples (UNDRIP) represents an important step towards the recognition and protection of indigenous peoples' rights at international level. It acknowledges numerous collective rights, including the right to self-determination and the right to cultural heritage and intellectual property. References to land rights can be found throughout the Declaration. Article 26 is one of the key provisions; it is far reaching, especially in recognizing that indigenous peoples have a right over the lands they have traditionally owned and have control over the resources that they possess. It also acknowledges that states must give legal recognition to these lands and that customary land tenure must be respected. Article 32 requires states to obtain the free, prior and informed consent of indigenous peoples before approving projects that can affect theirlands.

Keywords: rights to natural resources, indigenous peoples rights, international law, ILO Convention 169, natural resources.

\section{A. Pendahuluan}

Istilah 'indigenous peoples' mulai dikenal di seluruh dunia dan semakin diakui oleh banyak negara, setelah International Labour Organization (ILO) ${ }^{1}$ mendeklarasikan Convention Concerning Indigenous and Tribal Peoples in Independent Countries (Konvensi ILO 169) ${ }^{2}$ tanggal 27 Juni 1989. Istilah indigeneous peoples ${ }^{3}$ yang digunakan

1 International Labour Organization (ILO) merupakan badan khusus PBB yang bertugas memajukan kesempatan bagi laki-laki dan perempuan untuk memperoleh pekerjaan yang layak dan produktif dalam kondisi yang merdeka, setara, aman, dan bermartabat. Tujuan utama ILO adalah mempromosikan hak-hak kerja, memperluas kesempatan kerja yang layak, meningkatkan perlindungan sosial, dan memperkuat dialog dalam menangani berbagai masalah terkait dengan dunia kerja.

2 ILO Convention 169 concerning Indigenous and Tribal Peoples in Independent Countries (Geneva, 29 Juni 1989) menggantikan ILO Convention 107 concerning the Protection and Integration of Indigenous and Other Tribal and Semi-tribal Populations in Independent Countries (Geneva, 2 Juni 1959). Konvensi ini berlaku mengikat sejak 5 September 1991.

3 Istilah 'indigenous and tribal peoples' dalam Konvensi ini diterjemahkan menjadi 'masyarakat hukum adat' sesuai dengan istilah yang dipergunakan Komisi Nasional Hak Asasi Manusia (HAM) dan Mahkamah Konstitusi Republik Indonesia. Terjemahan lain yang umum digunakan adalah masyarakat adat dan masyarakat tradisional. Dalam 
dalam Konvensi ILO 169 juga diadopsi oleh World Bank dalam pelaksanaan proyek pendanaan pembangunan di sejumlah negara, terutama di negara-negara ketiga, seperti di Amerika Latin, Afrika, dan Asia Pasifik.

Masyarakat hukum adat dan eksistensinya selalu menjadi topik yang menarik dan sering menimbulkan perdebatan, terutama sekali apabila masyarakat hukum adat beserta hak-haknya dihadapkan dengan kepentingan negara atau pemerintah. Dari sekian banyak hak-hak masyarakat hukum adat, hak atas pengelolaan sumber daya alam menjadi topik yang menarik karena sumber daya alam memiliki peran yang besar dalam rangka mempertahankan eksistensi masyarakat hukum adat mengingat mereka menggantungkan hidupnya pada sumber daya alam di tempat mereka tinggal.

Sekarang ini, sekitar 370 juta orang yang merupakan anggota masyarakat hukum adat yang hidup di lebih dari 70 negara di seluruh dunia, merupakan $5 \%$ dari seluruh penduduk dunia. Sementara itu, $80 \%$ dari seluruh keanekaragaman hayati di planet bumi ini tumbuh subur di $22 \%$ dari wilayah bumi yang merupakan tempat tinggal masyarakat hukum adat. ${ }^{4}$ Para peneliti menyatakan bahwa ketika keanekaragaman hayati terancam, maka akan mengancam juga hubungan antara masyarakat hukum adat dengan tanah air mereka yang sudah berlangsung lama dan turun temurun, serta akan mengancam kesehatan dan kesejahteraan masyarakat hukum adat. Kerusakan lingkungan yang terus terjadi membahayakan kelanjutan hubungan mereka dengan lingkungannya yang sudah dipraktikkan selama ribuan tahun, seperti mengumpulkan obat-obatan, berburu, memancing, dan kegiatan pertanian. ${ }^{5}$

The Word Commission on the Social Dimension of Globalization yang dibentuk oleh ILO pada Februari 2002, dalam laporannya yang berjudul "A Fair Globalization: Creating Opportunities for All", ${ }^{6}$ mengkaji berbagai aspek globalisasi dan implikasinya bagi kemajuan ekonomi dan sosial. Komisi ini berupaya untuk menyelaraskan antara tujuan sosial, ekonomi, dan lingkungan. Komisi ini mengakui bahwa diperlukan upaya

pertemuan yang bertajuk "Lokakarya Pengembangan Sumber Daya Hukum Masyarakat Adat tentang Pengelolaan Sumber Daya Alam di dalam Kawasan Hutan”, yang berlangsung pada tanggal 25-29 Mei 1993, di Toraja Sulawesi Selatan, istilah indigenous peoples' diadopsi dan diterjemahkan menjadi kosa kata 'masyarakat adat'. Isu masyarakat adat semakin memperoleh tempatnya dalam gerakan masyarakat sipil melalui pendeklarasian pembentukan Aliansi Masyarakat Adat Nusantara (AMAN) pada tahun 1999 di Jakarta.

4 United Nations Development Programme, “Human Development Report 2011 Sustainability and Equity: A Better Future for All", New York: Palgrave Macmillan, 2011, hlm. 54.

5 Jeff Corntassel and Cheryl Bryce, "Practicing Sustainable Self-Determination: Indigenous Approaches to Cultural Restoration and Revitalization", Brown Journal of World Affairs, Volume XVIII, Issue II, Spring/Summer 2012, hlm. 151.

6 World Commission on the Social Dimension of Globalization. "A Fair Globalization: Creating Opportunities for All”, (www.ilo.org/public/english/wcsdg/docs/report.pdf), first published as an ILO publication in February 2004, reprinted in April 2004. 
untuk membela hak-hak masyarakat adat atas wilayah dan sumber daya, budaya dan identitas mereka, pengetahuan tradisional, dan hak mereka untuk menentukan nasib sendiri, baik pada tingkat lokal, maupun nasional. ${ }^{7}$ Selain itu, komisi merekomendasikan bahwa prinsip free and prior informed consent (FPIC) harus diupayakan terlebih dahulu untuk memperoleh persetujuan masyarakat hukum adat sebelum kegiatan proyek pembangunan dilaksanakan. ${ }^{8}$

Komisi juga mencatat bahwa kegiatan industri pertambangan menimbulkan dampak negatif terhadap masyarakat hukum adat, masyarakat lokal, bahkan lingkungan tempat mereka berinteraksi. Selain itu, beberapa masyarakat hukum adat dari negara-negara tertentu mengangkat isu militerisasi tanah adat, termasuk pendirian pangkalan militer asing. Kenyataan di atas dan rekomendasi komisi mencerminkan, antara lain, pentingnya nilai tanah dan sumber daya alam bagi masyarakat hukum adat, tidak hanya untuk mereka dan negara tempat mereka tinggal, tetapi juga untuk seluruh masyarakat internasional.

Tulisan ini berupaya untuk menyajikan perkembangan instrumen hukum internasional terkait dengan perlindungan masyarakat hukum adat, khususnya hak atas pengelolaan sumber daya alam. Beberapa putusan pengadilan di beberapa negara terkait dengan sengketa masyarakat hukum adat mengenai pengelolaan sumber daya alam, walaupun secara singkat, juga akan dikemukakan dalam tulisan ini.

\section{B. Dinamika Hukum Pengakuan dan Perlindungan Hak Masyarakat Hukum Adat}

\section{Konsep Dinamika Hukum}

Hukum mempunyai dinamika yang dapat diketahui melalui penelusuran pemikiran dan kebijakan yang terjadi pada masa lampau, guna membenahi masa kini dan memprediksikan yang akan terjadi ke depan. ${ }^{9}$ Menurut Kelsen sebagaimana dikutip Sodiki, ${ }^{10}$ dinamika atau perubahan di bidang hukum berwujud perubahan hukum sebagai suatu sistem tertutup dan atau sistem terbuka. Perubahan hukum sebagai suatu sistem tertutup; dinamika internal hukum; jika mengutip pendapat Kelsen, yakni perubahan hukum yang berlangsung berdasarkan tingkatan hierarki hukum. Di samping itu, terdapat perubahan yang berlangsung di dalam masyarakat seperti ketaatan masyarakat terhadap hukum. Perubahan terakhir ini berupa perubahan

7 Ibid, hlm. 311 dan 312.

8 Ibid, hlm. 311.

9 Husen Alting, "Penguasaan Tanah Masyarakat Hukum Adat (Suatu Kajian terhadap Masyarakat Hukum Adat Ternate)", Jurnal Dinamika Hukum, Volume 11 Nomor 1, Januari 2011, hlm. 89.

10 Achmad Sodiki, "Penataan Kepemilikan Hak atas Tanah di Daerah Perkebunan Kabupaten Malang (Studi tentang Dinamika Hukum)", Disertasi, Program Pascasarjana Universitas Airlangga, Surabaya, 1994, hlm. 43. 
nilai-nilai, sikap, dan tingkah laku masyarakat terhadap hukum, atau dengan perkataan lain, adanya dinamika eksternal hukum. ${ }^{11}$ Perubahan hukum yang mengatur permasalahan pertanahan sangat bergantung pada politik hukum pemerintah, sekaligus dipengaruhi oleh konstelasi politik yang terjadi pada saat itu. ${ }^{12}$ Dalam kehidupan bernegara, fenomena sosial dan hukum itulah yang kemudian mengkristal dalam bentuk peraturan perundang-undangan.

Pandangan lain dikemukakan oleh Luhmann melalui teori yang disebut the theory of society as functionally differentiated social system'. ${ }^{13}$ Berdasarkan pendapat Luhmann, sistem hukum adalah suatu sistem yang normatif tertutup (normative closed system). Meskipun demikian, pada saat yang sama sistem hukum juga merupakan sistem yang kognitif terbuka (cognitive open system). Ketertutupan dan keterbukaan bukan merupakan kontradiksi, melainkan dua kondisi yang timbal balik.

Sebagai suatu sistem yang secara normatif tertutup, kedudukan antarkomponen sistem adalah simetris, sedangkan hubungan dengan lingkungan bersifat asimetris. Operasional sistem bergantung kepada lingkungan dan menyesuaikan diri dengan perubahan kondisi. Teori "Self referential legal system" membedakan antara normatif dan kognitif orientasi sekaligus juga membedakan dan mengombinasikan antara keterbukaan dan ketertutupan sistem tersebut. ${ }^{14}$

Selama ini, politik hukum penguasaan tanah yang diberlakukan Pemerintah Indonesia bersifat normatif (hukum negara) dan sangat tertutup terhadap fakta sosial (pluralisme hukum) dalam masyarakat yang masih teguh mempertahankan dan melaksanakan penguasaan dan pengelolaan tanah berdasarkan hukum adat. Padahal sangat banyak konsep dan asas-asas hukum adat yang dapat memberikan kontribusi terhadap pembentukan hukum nasional.

\section{Konsep Pengakuan dan Perlindungan}

Pengakuan (erkenning) ${ }^{15}$ secara terminologi berarti proses, cara, perbuatan mengaku atau mengakui, sedangkan mengakui berarti 'menyatakan berhak'. Pengakuan dalam konteks eksistensi suatu negara, yaitu keberadaan suatu negara atau pemerintahan yang secara nyata menjalankan kekuasaan efektif pada suatu wilayah yang disebut

11 Ibid, hlm. 44.

12 Lihat konfigurasi politik dan hukum dalam Mahfud M.D, Pergulatan Politik dan Hukum di Indonesia, Yogyakarta: Gamamedia, 1999, hlm. 4. Bandingkan dengan Hasnati, "Pertautan Kekuasaan Politik dan Negara Hukum", Jurnal Hukum Respublica, Volume 3 Nomor 1, Tahun 2003, Pekanbaru: Fakultas Hukum Universitas Lancang Kuning, hlm. 102-113.

13 Niklas Luhmann, "The Self Reproduction of law and its Limits" dalam: Gunter Teubner (ed.), Dilema of Law in the Welfare State, New York: Walter de Gruyter, 1988, hlm. 112.

14 Ibid, hlm. 48.

15 Husen Alting, Op.cit., hlm. 89. 
dengan pengakuan de facto, selain pengakuan secara hukum (de jure) yang diikuti dengan tindakan-tindakan hukum tertentu, seperti pertukaran diplomatik dan pembuatan perjanjian-perjanjian kedua negara.

Kelsen, dalam bukunya "General Theory of Law and State", 16 menguraikan pengakuan dalam kaitan dengan keberadaan suatu negara sebagai berikut:

Terdapat dua tindakan dalam suatu pengakuan, yakni tindakan politik dan tindakan hukum. Tindakan politik mengakui suatu negara (baca: keberadaan masyarakat hukum adat-penulis) berarti negara mengakui dan berkehendak untuk mengadakan hubungan-hubungan politik dan hubungan-hubungan lain dengan masyarakat yang diakuinya, sedangkan tindakan hukum adalah prosedur yang dikemukakan di atas yang ditetapkan oleh hukum internasional (baca: hukum nasional-penulis) untuk menetapkan fakta negara (baca: masyarakat adat-penulis) dalam suatu kasus kongkret.

Penetapan hukum negara (hukum positif) sebagai satu-satunya hukum yang mengatur kehidupan masyarakat, kemudian dikritisi oleh para pengikut mazhab sejarah yang meyakini bahwa setiap masyarakat memiliki ciri khas masing-masing, bergantung pada riwayat hidup dan struktur sosial yang hidup dan berkembang dalam mengatur kepentingan mereka. Savigny melihat bahwa hukum sebagai fenomena historis sehingga keberadaan setiap hukum berbeda, bergantung kepada tempat dan waktu berlakunya hukum tersebut. Hukum harus dipandang sebagai penjelmaan jiwa atau rohani suatu bangsa (Volksgeits). ${ }^{17}$

Konsep volksgeist Savigny tersebut dipertegas oleh Ehrlich yang menyebutkan dengan fakta-fakta hukum (fact of law) dan hukum yang hidup dalam masyarakat (living law of people) yang berpandangan bahwa dalam setiap masyarakat terdapat aturan hukum yang hidup (living law). Semua hukum merupakan hukum sosial, dalam arti bahwa semua hubungan hukum ditandai dengan adanya faktor-faktor sosial dan ekonomi.

Pengakuan bersyarat yang selama ini diterapkan oleh pemerintah (sepanjang masih ada dan tidak bertentangan dengan peraturan perundang-undangan), ${ }^{18}$ sebagaimana dicantumkan dalam UUD 1945, hal ini sangat merugikan eksistensi dari

16 Hans Kelsen, Teori umum tentang Hukum dan Negara, terjemahan Sumarno, Jakarta: Rimdi Press, 1973, hlm. 222.

17 Lihat: Farida Patittingi, "Peranan Hukum Adat dalam Pembinaan Hukum Nasional dalam Era Globalisasi", Majalah IImu Hukum Amanna Gappa, Volume 11 Nomor 13, Januari-Maret 2003, Makassar: Fakultas Hukum Universitas Hasanudin, hlm. 411.

18 Lihat penjelasan tentang hal ini pada Jufrina Rizal, "Perkembangan Hukum Adat sebagai Living Law dalam Masyarakat", Jurnal IImu Hukum Amanna Gappa, Volume 16 Nomor 1, Maret 2008, Makassar: Fakultas Hukum Universitas Hasanudin, hlm. 27. 
masyarakat adat. Hal ini disebabkan oleh bentuk pengakuan terbatas yang persyaratan pengakuan tersebut diserahkan kepada politik hukum negara dalam mengakui dan melindungi hak-hak masyarakat adat. Dengan demikian, dapat dikatakan bahwa telah terjadi penundukan hukum adat terhadap hukum negara, yang oleh Griffiths disebut sebagai pluralisme hukum lemah, ${ }^{19}$ yaitu pemberlakuan hukum adat hanya dapat dimungkinkan dengan pengakuan dari hukum negara terlebih dahulu.

\section{Konsep Hak Masyarakat Hukum Adat}

Adat istiadat mempunyai ikatan dan pengaruh yang kuat dalam masyarakat. Kekuatan mengikat bergantung pada masyarakat yang mendukung adat istiadat tersebut, terutama berpangkal tolak pada perasaan kebersamaan, idealisme, dan keadilan. Sulit untuk dibayangkan bahwa adat istiadat, walaupun dipelihara terus-menerus, dengan sendirinya akan mewujudkan kepastian hukum jika terdapat kaidah-kaidah mengikat yang mengatur tata kehidupan masa kini dan masa yang akan datang. ${ }^{20}$

Membedakan adat dan hukum adat dapat dilihat dari kaidah-kaidah yang hidup dalam masyarakat dan diberikan sanksi bagi pihak yang melanggar kaidah tersebut. Malinowski menyatakan bahwa perbedaan kebiasaan dengan hukum berdasarkan pada dua kriteria, yakni sumber sanksi dan pelaksanaannya. Pada kebiasaan sumber sanksi dan pelaksanaannya ada pada warga masyarakat secara individu dan kelompok, sedangkan pada hukum sanksi dan pelaksanaannya ada pada suatu kekuatan terpusat atau badan-badan tertentu dalam masyarakat.

Penilaian pakar hukum di atas menurut penulis lebih cenderung melihat hukum adat dari aspek sanksi yang diterapkan oleh suatu otoritas atau penguasa, ketika suatu individu melakukan pelanggaran atas norma yang disepakati. Meskipun demikian, tidak selamanya hukum adat tersebut identik dengan pemberian sanksi. Pada masyarakat tertentu, sanksi merupakan alternatif terakhir ketika seseorang tidak menaati norma yang hidup dalam masyarakat. Hal yang terpenting bagi masyarakat adalah hukum adat tersebut dapat memberikan rasa aman dan menciptakan ketertiban dalam hubungan sosial. Sanksi tidak selamanya diberikan oleh suatu otoritas atau institusi yang berkuasa, tetapi ada juga yang diberikan oleh

19 Lihat penjelasan konsep ini dalam Bernard Steny, "Pluralisme Hukum: Antara Perda Pengakuan Masyarakat Adat dan Otonomi Hukum Lokal", Jurnal Pembaruan Desa dan Agraria, Volume 3 Nomor 3, Tahun 2006, hlm. 84-85.

20 Penjelasan panjang lebar mengenai hal ini dapat dibaca pada Achmad Sodiki, "Masalah Konflik Peraturan Perundang-undangan dan Konflik di Lapangan Agraria dan Usulan Penanganannya (Mencari Format Penanganan Konflik Agraria dalam Rangka Implementasi Ketatapan MPR No.IX/MPR/2001)", Makalah, Disampaikan sebagai Penanggap Utama dalam Seminar Nasional Strategi Pelaksanaan Pembaharuan Agraria, 26 September 2002, Jakarta, hlm. 3; Lihat juga Teddy Anggoro,"Kajian Hukum Masyarakat Hukum Adat dan HAM dalam Lingkup Negara Kesatuan Republik Indonesia", Jurnal Hukum dan Pembangunan, Volume 36 Nomor 4, OktoberDesember 2006, Jakarta: Fakultas Hukum Universitas Indonesia, hlm. 489. 
masyarakat secara langsung melalui pembatasan pergaulan atau interaksi sosial yang dilakukan.

Dapat disimpulkan bahwa hukum adat ${ }^{21}$ yang dimaknai dalam penulisan ini adalah hukum adat yang mengandung unsur-unsur pembentuknya, seperti terdapat adat istiadat sebagai nilai-nilai yang telah melembaga dalam masyarakat melalui perbuatan-perbuatan masyarakat, mengandung norma yang berdasarkan kesepakatan bersama secara tidak tertulis, memiliki institusi atau organisasi yang menegakkan, memiliki sanksi, serta dipengaruhi oleh agama yang dianut pada masyarakat. Nilai-nilai dan norma-norma yang telah didapatkan berdasarkan kesepakatan masa lalu, dalam kehidupan modern masih menjadi rujukan sebagai kearifan lokal (local wisdom). ${ }^{22}$

Selanjutnya, menurut penulis, secara substansial memberikan pemahaman bahwa hukum adat merupakan hukum yang selalu hidup dan berkembang dalam masyarakat, yang selalu mengikuti perkembangan zaman, memberikan jaminan ketertiban bagi masyarakat, serta mampu memberikan keadilan. Hukum adat bertujuan menciptakan kedamaian dan meningkatkan kesejahteraan bagi masyarakat. Di samping itu, hak masyarakat hukum adat merupakan hak yang bersifat individu atau hak yang bersifat komunal. Salah satu hak yang bersifat komunal yang terdapat dalam Undang-Undang Pemerintahan Aceh (UUPA) adalah hak ulayat (wilayah) untuk menunjukkan bahwa tanah merupakan wilayah lingkungan masyarakat hukum bersangkutan.

Menurut Sodiki, konsep penguasaan tanah yang berlaku pada masyarakat tradisional, antara lain hak ulayat, yaitu suatu hak masyarakat hukum sebagai suatu kesatuan yang mempunyai wewenang ke luar dan ke dalam, serta di dalamnya terdapat hak individu atas tanah, yakni hak yang lahir karena pengusahaan yang terus menerus secara intensif atas sebidang tanah (kosong). ${ }^{23}$ Muchsin mendefinisikan hak ulayat sebagai hak yang dimiliki oleh masyarakat hukum adat atas wilayah tertentu yang merupakan lingkungan hidup para warganya untuk mengambil manfaat dari sumber daya alam, termasuk tanah di dalam wilayah tersebut bagi kelangsungan

21 Istilah 'masyarakat adat' diambil dari terjemahan kata 'indigenous peoples' yang dibedakan dengan istilah 'Masyarakat Hukum Adat' yang merupakan terjemahan dari bahasa Belanda yakni 'rechtgemencshap'. Lihat: Masyhud Asyhari, "Pemberdayaan Hak-Hak Rakyat atas Tanah", Jurnal Hukum lus Quia lustum, Volume 13 Nomor 7, April 2000, hlm, 108-109; Jawahir Thontowi, "Komunitas Lokal dalam Perspektif HAM dan Hukum Nasional", Jurnal Hukum, Volume 57, Juli 2005, hlm. 245.

22 Jawahir Thontowi, Op. cit, hlm. 239-240. Lihat juga Rachmad Syafa'at, "Kearifan Lokal dalam Masyarakat Adat di Indonesia", Jurnal Publica, Volume 4 Nomor 1, Januari 2008, Malang: FISIP UMM, hlm. 8-15.

23 Achmad Sodiki, "Penataan Kepemilikan Hak atas Tanah di Daerah Perkebunan Kabupaten Malang (Studi tentang Dinamika Hukum)", Disertasi, Program Pascasarjana Universitas Airlangga, Surabaya, 1994, hlm. 21. 
hidup dan kehidupannya. ${ }^{24}$ Pengakuan terhadap hak ulayat ini menunjukkan adanya kebolehan warga negara, secara adat, untuk memiliki atau menguasai tanah secara kolektif bagi pemenuhan kepentingan bersama dan juga pengakuan hak atas tanah secara pribadi. ${ }^{25}$

\section{Hak Masyarakat Hukum Adat atas Sumber Daya Alam dalam Hukum Internasional}

Masyarakat adat sebagai bagian dari rakyat secara keseluruhan suatu bangsa atau negara, memiliki kepentingan yang harus dihormati oleh pemerintah atau negara, terutama berkaitan dengan pemanfaatan sumber daya alam. Pemerintah berkewajiban memenuhi kepentingan pembangunan dan kesejahteraan rakyat, termasuk indigenous peoples, dalam pengelolaan dan pemanfaatan sumber daya alam. Kewajiban tersebut diatur dalam beberapa ketentuan hukum internasional, misalnya Resolusi Majelis Umum Perserikatan Bangsa-Bangsa (PBB) No. 41/128 tentang Declaration on The Right to Development. Pasal 1 ayat (1) butir 2 deklarasi menyatakan bahwa:

"The right to development is an inalienable right by virtue of which every human person and all peoples are entitled to participate in, contribute to, and enjoy economic, social, cultural, and political development, in which all human rights and fundamental freedom can be fully realized."

Dalam Pasal 2 ayat (1) deklarasi tersebut, dinyatakan: "The human person is the central subject of development and should be the active participant and beneficiary of the right to development." Demikian juga dalam Pasal 2 Ayat (3) dinyatakan bahwa:

"States have the right and duty to formulate the appropriate national development policies that aim at the constant improvement of the well-being of the entire population and of all individuals, on the basis of their active, free, and meaningfully participation in development, and in the fair distribution of the benefits resulting there from."

Ketentuan di atas menunjukkan bahwa negara berkewajiban untuk memenuhi kebutuhan pembangunan rakyat di segala bidang, baik sebagai individu, maupun kelompok. Selain itu, negara berkewajiban mengikutsertakan rakyat dalam proses pembangunan, serta secara adil mendistribusikan hasil-hasil pembangunan kepada seluruh rakyat, tidak terkecuali terhadap penduduk asli.

24 Muchsin, "Kedudukan Tanah Ulayat dalam Sistem Hukum Tanah Nasional", Varia Peradilan, XXI (245) April 2006, Jakarta : Ikahi, hlm. 35.

25 Ni'matul Huda, "Beberapa Kendala dalam Penyelesaian Status Hukum Tanah Bekas Swapraja di Daerah Istimewa Yogyakarta", Jurnal Hukum, Volume 13 Nomor 7 April 2000, Yogyakarta: Fakultas Hukum UN, hlm. 108. 
Perlindungan hak masyarakat adat terhadap sumber daya alam berkembang semakin baik. Berbagai instrumen hukum internasional lainnya, baik dalam bentuk hard law, maupun soft law, mengatur secara jelas tentang perlindungan masyarakat adat dalam pengelolaan sumber daya alam.

\section{Convention Concerning Indigenous and Tribal Peoples in Independent Countries (Konvensi ILO 169)}

Konvensi ILO 169 merupakan instrumen hukum internasional yang pertama yang mengikat secara hukum yang mengatur tentang hak-hak masyarakat adat. Konvensi ILO 169 menentukan prinsip dasar mengenai indigenous peoples dan tribal peoples. Konvensi ini berlaku bagi masyarakat hukum adat di negara-negara merdeka yang kondisi sosial, budaya, dan ekonominya membedakan mereka dari unsur-unsur lain masyarakat nasional dan yang statusnya diatur secara keseluruhan atau sebagian oleh adat atau tradisi mereka sendiri atau oleh undang-undang atau peraturanperaturan khusus. ${ }^{26}$

Masyarakat hukum adat di negara-negara merdeka dianggap sebagai pribumi karena mereka adalah keturunan dari penduduk yang mendiami negara yang bersangkutan atau berdasarkan wilayah geografis tempat negara yang bersangkutan berada. Juga pada waktu penaklukan atau penjajahan atau penetapan batas-batas negara saat ini tanpa memandang status hukum mereka, tetap mempertahankan beberapa atau seluruh institusi sosial, ekonomi, budaya, dan politik mereka sendiri. ${ }^{27}$

Dalam Pasal 2 ayat (1) konvensi ini, dinyatakan bahwa pemerintah mempunyai tanggung jawab untuk menyusun, dengan partisipasi dari masyarakat hukum adat yang bersangkutan, aksi yang terkoordinasi dan sistematis untuk melindungi hak-hak dan menjamin dihormatinya keutuhan mereka. Aksi tersebut meliputi langkahlangkah untuk:

(1) memastikan bahwa para anggota dari masyarakat hukum adat ini mendapat manfaat berdasarkan kesetaraan derajat dari hak-hak dan kesempatankesempatan yang diberikan oleh undang-undang dan peraturan-peraturan nasional kepada anggota-anggota lainnya dari penduduk negara tempat mereka tinggal; ${ }^{28}$

(2) mengupayakan terwujudnya secara penuh hak-hak sosial, ekonomi, dan budaya dari masyarakat hukum adat ini dengan penghormatan terhadap identitas sosial dan budaya mereka, adat-istiadat dan tradisi mereka, serta institusi-institusi mereka; ${ }^{29}$

26 Pasal 1 ayat (1) huruf a Konvensi ILO 169.

27 Pasal 1 ayat (1) huruf b Konvensi ILO 169.

28 Pasal 2 ayat (2) huruf a Konvensi ILO 169.

29 Pasal 2 ayat (2) huruf b Konvensi ILO 169. 
(3) membantu para anggota dari masyarakat hukum adat yang bersangkutan untuk menghapus kesenjangan sosial dan ekonomi yang dapat terjadi antara pribumi dan anggota-anggota lain masyarakat nasional, dengan cara yang sesuai dengan aspirasi dan cara hidup mereka. ${ }^{30}$

Sejalan dengan Konvensi ILO 169, Durning menyebutkan beberapa kriteria penduduk asli, yaitu paling tidak memiliki lima elemen dasar sebagai berikut: ${ }^{31}$

a. keturunan penduduk asli suatu daerah yang kemudian dihuni oleh sekelompok masyarakat dari luar yang lebih kuat;

b. sekelompok orang yang mempunyai bahasa, tradisi, budaya, dan agama yang berbeda dengan kelompok yang lebih dominan;

c. selalu diasosiasikan dengan beberapa tipe kondisi ekonomi masyarakat;

d. keturunan masyarakat pemburu, nomadik, dan peladang berpindah;

e. masyarakat dengan hubungan sosial yang menekankan pada hubungan kelompok, pengambilan keputusan melalui kesepakatan, serta pengelolaan sumber daya secara kelompok.

Menurut Cobo, 32 pengertian indigenous peoples adalah sebagai berikut:

"Indigenous peoples, communities and nations are those which, having a historical continuity with pre-invasion and pre-colonial societies that developed on their territories considers themselves distinct from other sector of the societies now prevailing in those territories, or part of them. They form at present non-dominant sectors of society and are determined to preserve, develop and transmit to future generations their ancestral territories, and their ethnic identity, as the basis of their continued existence as peoples, in accordance with their own cultural patterns, social institutions and legal system."

Berdasarkan batasan-batasan di atas, dapat disimpulkan bahwa indigenous peoples adalah penduduk atau kelompok masyarakat dari suatu bangsa atau negara yang rentan terhadap penindasan dan ketertinggalan. Umumnya yang disebut penduduk asli dari suatu negara adalah mereka atau kelompok penduduk yang sangat tradisional dan jauh dari sentuhan teknologi dan kemajuan; golongan penduduk yang sangat jauh tertinggal dibandingkan dengan golongan penduduk lainnya, padahal mereka umumnya memiliki lingkungan dengan sumber daya alam yang sangat potensial. Sistem dan tatanan hukum sebelumnyalah yang menyebabkan mereka

30 Pasal 2 ayat (2) huruf c Konvensi ILO 169.

31 Bruce Mitchell, B. Setiawan, dan Dwita Hadi Rahmi, Pengelolaan Sumber Daya dan Lingkungan, Yogyakarta: Gadjah Mada University Press, 2000, hlm. 299.

32 Nico Schijver, Sovereignty Over Natural Resource, Cambridge: Cambridge University Press, 1997, hlm. 312. 
selalu tertinggal. Eksploitasi terhadap lingkungan dan sumber daya alam sedikit pun tidak menyentuh perbaikan kesejahteraan mereka. Sebaliknya hanya memberikan keuntungan kepada segelintir golongan penduduk yang lainnya. Belum lagi keuntungan yang tidak diraih oleh penduduk asli. Oleh karena itu, yang paling berpotensi menderita kerugian di kemudian hari akibat dampak dari kegiatan tersebut adalah penduduk asli.

Konvensi ILO 169 memuat beberapa pasal penting yang secara khusus mengatur tentang isu tanah. Dalam Pasal 14, dinyatakan bahwa: ${ }^{33}$

"The rights of ownership and possession of the peoples concerned over the lands which they traditionally occupy shall be recognised. In addition, measures shall be taken in appropriate cases to safeguard the right of the peoples concerned to use lands not exclusively occupied by them, but to which they have traditionally had access for their subsistence and traditional activities."

Dengan kata lain, ketentuan Pasal 14 ini memaksa negara untuk mengakui hak penguasaan dan kepemilikan masyarakat adat. Apabila tidak mengakui, negara akan melanggar hak-hak masyarakat adat tersebut. ${ }^{34}$

Selain itu, konvensi ILO 169 memuat ketentuan penting mengenai penguasaan masyarakat hukum adat atas sumber daya alam. Secara khusus, dalam Pasal 15 diatur hak-hak masyarakat hukum adat terhadap sumber daya alam. Dalam ketentuan ayat (1), dinyatakan sebagai berikut:

"The rights of the people concerned to the natural resources pertaining to their lands shall be specially safeguarded. These rights include the right of these peoples to participate in the use, management and conservation of these resources."

Penduduk asli berhak atas terpeliharanya sumber daya alam, termasuk di dalamnya hak untuk berpartisipasi dalam pengelolaan, pemanfaatan, dan konservasi sumber daya tersebut. Dengan demikian, realisasi terhadap pelaksanaan hak-hak penduduk asli merupakan kewajiban negara atau pemerintah.

Konvensi ILO 169 merupakan instrumen hukum internasional pertama yang mengakui hak-hak masyarakat adat yang bersifat kolektif. Dalam konvensi ini, juga diakui hak-hak masyarakat adat yang penting, seperti free dan informed consent, consultation, dan compensation. Dalam mengambil keputusan mengenai suatu

33 Lihat: Pasal 14 ayat (1) ILO Convention 169.

34 Sophie Lemaitre, "Indigenous Peoples' Land Rights and REDD: A Case Study", Review of European Community \& International Environmental Law (RECIEL) 20 (2) 2011, hIm. 152. 
kegiatan yang akan berpengaruh terhadap mereka, pemerintah harus mengonsultasikannya dengan masyarakat hukum adat yang bersangkutan melalui prosedur-prosedur yang berlaku, terutama melalui institusi-institusi perwakilan mereka, atau setiap kali sedang melakukan pertimbangan terhadap upaya-upaya legislatif atau administratif yang dapat langsung berpengaruh terhadap mereka. ${ }^{35}$ Pemerintah juga harus menetapkan cara-cara yang memungkinkan masyarakat hukum adat ini untuk dapat secara bebas berpartisipasi, sekurang-kurangnya pada tingkat yang sama seperti sektor-sektor lainnya dalam populasi, di seluruh tingkat pengambilan keputusan dalam institusi-institusi pemilihan umum dan administrasi, dan badan-badan lain yang bertanggung jawab atas kebijakan-kebijakan dan program-program yang menyangkut kepentingan mereka.

Bila pemindahan masyarakat hukum adat ini ke tempat lain dianggap perlu sebagai suatu langkah pengecualian, pemindahan ke tempat lain tersebut hanya boleh berlangsung jika mereka, dengan kehendak bebas yang mereka miliki, menyetujuinya setelah mereka memaklumi akibat-akibatnya. Jika tidak dapat diperoleh persetujuan dari mereka, pemindahan ke tempat lain tersebut hanya boleh berlangsung dengan mengikuti prosedur-prosedur semestinya yang ditetapkan oleh peraturan perundang-undangan nasional, termasuk dengan cara mengumpulkan pendapat umum jika dipandang tepat atau patut dilakukan, sehingga memberikan kesempatan bagi masyarakat hukum adat yang bersangkutan untuk dapat terwakili kepentingannya secara efektif. ${ }^{36}$

Apabila terdapat situasi, yaitu negara tetap mempertahankan kepemilikan atas sumber-sumber daya mineral atau sumber-sumber daya yang terdapat di bawah permukaan tanah atau hak-hak atas sumber daya lain yang menyangkut tanah, pemerintah harus menetapkan prosedur yang mengharuskan mereka untuk mengonsultasikannya dengan masyarakat hukum adat untuk mendapatkan keterangan yang benar tentang apakah dan hingga sejauh mana kepentingan masyarakat hukum adat akan dirugikan sebelum menjalankan atau mengizinkan program-program apapun untuk mengeksplorasi atau mengeksploitasi sumbersumber daya tersebut yang menyangkut tanah-tanah mereka. Masyarakat hukum adat yang bersangkutan harus (jika memungkinkan) ikut mendapatkan manfaat dari kegiatan-kegiatan tersebut dan harus menerima ganti rugi (kompensasi) yang adil atas setiap kerusakan atau kerugian yang dapat timbul yang harus mereka tanggung sebagai akibat dari kegiatan-kegiatan tersebut. ${ }^{37}$

35 Pasal 6 ayat (1) huruf a Konvensi ILO 169.

36 Pasal 16 ayat (2) ILO Convention 169.

37 Lihat Pasal 15 ayat (2) ILO Convention 169. 
Dalam Pasal 16 ayat (3) konvensi, dinyatakan, "Whenever possible, these peoples shall have the right to return to their traditional lands, as soon as the grounds for relocation cease to exist". Ketika kepulangan seperti itu tidak mungkin, sebagaimana ditetapkan oleh perjanjian atau dalam hal tidak adanya perjanjian seperti itu, melalui prosedur-prosedur yang tepat masyarakat hukum adat ini harus, dalam semua situasi yang mungkin, diberi tanah-tanah yang mutu dan status hukumnya sekurangkurangnya sama dengan tanah-tanah yang sebelumnya mereka tempati, yaitu yang sesuai untuk memenuhi kebutuhan-kebutuhan mereka saat ini dan perkembangan di masa yang akan datang. Bila masyarakat hukum adat bersangkutan menyatakan lebih menyukai atau memilih ganti rugi dalam bentuk uang atau barang, mereka harus diberi ganti rugi sesuai permintaan tersebut di bawah jaminan-jaminan yang tepat dan patut. ${ }^{38}$

Ketentuan beberapa pasal konvensi tersebut, yang mewajibkan pelaksanaan kegiatan yang berpengaruh terhadap kehidupan masyarakat adat, mengadopsi prinsip free and prior informed consent (FPIC). ${ }^{39}$ Oleh karena itu, masyarakat hukum adat dan/atau masyarakat lokal yang akan menerima dampak dari implementasi sebuah kegiatan harus berada pada posisi sebagai subjek utama dalam FPIC, misalnya masyarakat hukum adat dan masyarakat lokal yang kehidupannya bergantung pada sumber daya hutan (forest dependent community), haruslah menjadi subjek utama dalam implementasi proyek REDD+.

Keharusan memosisikan masyarakat hukum adat sebagai subjek utama dalam FPIC dalam pelaksanaan kegiatan REDD+ di Indonesia merupakan hal yang penting dan menentukan bagi keberhasilan program tersebut. Tidak dapat dipungkiri bahwa proyek REDD+ akan menimbulkan dampak bagi masyarakat yang bermukim di dalam dan di sekitar kawasan hutan. Kegiatan REDD+ di kawasan tersebut akan sukses jika mendapat dukungan dari masyarakat hukum adat dan/atau masyarakat lokal, terutama yang bermukim di dalam dan di sekitar kawasan hutan dan/atau ekosistem hutan. ${ }^{40}$

Hak masyarakat hukum adat atas sumber daya alam yang berkaitan dengan tanah-tanah mereka harus secara khusus dilindungi. Hak tersebut termasuk hak

38 Lihat Pasal 16 ayat (4) ILO Convention 169.

39 Free and Prior Informed Consent (FPIC) adalah satu proses yang memungkinkan masyarakat hukum adat dan/atau masyarakat lokal untuk menjalankan hak-hak fundamentalnya untuk menyatakan apakah mereka setuju atau tidak setuju terhadap sebuah aktivitas, proyek, atau kebijakan yang akan dilaksanakan di ruang kehidupan masyarakat dan berpotensi berdampak kepada tanah, kawasan, sumber daya, dan perikehidupan masyarakat.

40 Dewan Kehutanan Nasional dan UN-REDD Programme Indonesia "Rekomendasi Kebijakan: Instrumen Free, Prior Informed Consent (FPIC) bagi masyarakat adat dan/atau masyarakat lokal yang akan Terkena Dampak dalam Aktivitas REDD+ di Indonesia", Jakarta, 2011, hlm. 4. 
masyarakat hukum adat untuk berpartisipasi dalam pengelolaan dan konservasi sumber daya alam. Namun, keefektifan pelaksanaan konvensi ini tetap saja diragukan sebab masyarakat adat tidak diperbolehkan mengajukan complaints. Selain itu, konvensi ini hanya diratifikasi oleh 22 negara sampai pada September 2011.41 Meskipun demikian, ketentuan Konvensi ILO 169, khususnya tentang hak atas tanah memberikan pengaruh terhadap negara-negara dalam menyusun instrumen lainnya.

Negara Indonesia, meskipun belum meratifikasi Konvensi ILO 169, prinsip-prinsip pengakuan dan perlindungan terhadap hak masyarakat hukum adat atas sumber daya alam yang diatur konvensi, sudah diatur dalam Konstitusi Republik Indonesia. Pengakuan penting terhadap masyarakat hukum adat dan hak ulayat ditemukan dalam Undang-Undang Dasar (UUD 1945) hasil amandemen kedua. Pasal 18 B ayat (1) dan ayat (2) UUD 1945 menyebutkan:

(1) Negara mengakui dan menghormati satuan-satuan pemerintahan daerah yang bersifat khusus atau bersifat istimewa yang diatur dengan undang-undang;

(2) Negara mengakui dan menghormati kesatuan-kesatuan masyarakat hukum adat beserta hak-hak tradisionalnya sepanjang masih hidup dan sesuai dengan perkembangan masyarakat dan prinsip Negara Kesatuan Republik Indonesia, yang diatur dalam undang-undang.

Pasal ini, memberikan posisi konstitusional kepada masyarakat hukum adat dalam hubungannya dengan negara serta menjadi landasan konstitusional bagi penyelenggara negara, bagaimana seharusnya masyarakat hukum adat diperlakukan. Pasal tersebut adalah satu pernyataan tentang; (a) kewajiban konstitusional negara untuk mengakui dan menghormati masyarakat adat, serta (b) hak konstitusional masyarakat hukum adat untuk memperoleh pengakuan dan penghormatan terhadap hak-hak tradisionalnya. Apa yang termaktub dalam pasal 18 B ayat (2) tersebut sekaligus merupakan mandat konstitusi yang harus ditaati oleh penyelenggara negara, untuk mengatur pengakuan dan penghormatan atas keberadaan masyarakat adat dalam suatu bentuk undang-undang.

Walaupun negara mengakui dan menghormati keberadaan masyarakat hukum adat berserta hak ulayatnya secara deklaratif, tetapi dalam ketentuan Pasal 18 B ayat (2), ditentukan beberapa persyaratan yang harus dipenuhi oleh suatu masyarakat untuk dapat dikategorikan sebagai masyarakat hukum adat beserta hak ulayat yang dapat dinikmatinya secara aman. Persyaratan-persyaratan itu secara kumulatif adalah:

a. Sepanjang masih hidup

b. Sesuai dengan perkembangan masyarakat 
c. Sesuai dengan prinsip Negara Kesatuan Republik Indonesia

d. Diatur dalam undang-undang

Persyaratan konstitusional masyarakat hukum adat yang termuat di dalam Pasal 18 B ayat (2) UUD 1945 masih sangat umum. Oleh karena itu, Mahkamah Konstitusi Republik Indonesia ${ }^{42}$ memberikan penasfiran resmi di dalam salah satu putusannya untuk memperjelas kualifikasi dari masyarakat hukum adat. Dalam pertimbangan hukum Putusan Nomor 31/PUU-V/2007, Mahkamah Konstitusi telah memberikan penafsiran terhadap Pasal 18 B ayat (2) UUD 1945 juncto Pasal 41 ayat (1) huruf b Undang-Undang Mahkamah Konstitusi berkenaan dengan ada tidaknya kedudukan hukum (legal standing) kesatuan masyarakat hukum adat dalam upaya melindungi hak-hak konstitusionalnya.

Pengakuan bersyarat terhadap masyarakat adat dalam sejarah Republik Indonesia dimulai pada Undang-Undang Pokok Agraria (UUPA), Undang-Undang Kehutanan, Undang-Undang Pengairan, dan beberapa peraturan departemen dan lembaga pemerintahan. Setelah UUD 1945 mengadopsi empat persyaratan tersebut bagi masyarakat adat, kemudian berbagai undang-undang yang lahir pascaamandemen mengikuti alur tersebut, antara lain: Undang-Undang Sumber Daya Air, Undang-Undang Perikanan, dan Undang-Undang Perkebunan.

Pengakuan bersyarat ini mengindikasikan bahwa pemerintah masih belum bersungguh-sungguh membuat ketentuan untuk menghormati dan mengakui hak ulayat masyarakat hukum adat. Pengaturan tentang masyarakat adat dan hak ulayatnya, sampai hari ini, masih bersifat tidak jelas dan tidak tegas. Tidak jelas karena belum ada aturan yang kongkret tentang apa saja hak-hak yang terkait dengan keberadaan masyarakat yang dapat dinikmatinya. Dikatakan tidak tegas karena belum ada mekanisme penegakan yang dapat ditempuh dalam pemenuhan hak masyarakat adat, yang dapat dituntut di muka pengadilan (justiciable).

Persyaratan dalam Pasal 18 B ayat (2) beserta dengan serangkaian persyaratan yang dilanjutkan oleh beberapa Undang-Undang tentang Sumber Daya Alam menunjukkan bahwa negara dan pemerintah baru bisa mengakui dan menghormati hak ulayat masyarakat adat secara deklaratif, tetapi belum sampai pada tindakan hukum untuk melindungi dan memenuhi agar hak ulayat masyarakat adat dapat terpenuhi. Bahkan sama sekali belum menyentuh mekanisme penegakan hukum nasional bila terjadi pelanggaran terhadap hak ulayat yang sudah dianggap sebagai hak asasi manusia.

42 Lihat Putusan Nomor 31/PUU-V/2007 tertanggal 18 Juni 2008 melalui Website MK di: http://www.mahkamahkonstitusi.go.id/putusan/putusan_sidang_PUTUSAN\%2031\%20TUAL\%20dibaca\%2018 \%20Juni\%202008.pdf. 
Ketentuan konvensi ini digunakan sebagai acuan (referensi) dalam menangani kasus hukum domestik (misalnya, Bolivia, Argentina, dan Venezuela) dan pada pengadilan regional (seperti melalui sistem inter-Amerika tentang hak asasi manusia dalam kasus Yakye Axa Indigenous Community v. Paraguay tahun 2005 atau kasus Mayan Communities di District Toledo v. Belize tahun 2004), ${ }^{43}$ bahkan ketika negara yang bersangkutan belum meratifikasi konvensi (misalnya, dalam kasus Awas Tingni v. Nicaragua tahun $2001 .^{44}$

Selain Konvensi ILO 169, hak masyarakat hukum adat atas tanah dan sumber daya alam juga sudah diterima dalam instrumen internasional lainnya. Earth Summit di Rio de Janeiro pada 1992 menghasilkan Rio Declaration on Environment and Development (Deklarasi Rio 1992). Berdasarkan Prinsip ke-22 deklarasi ini, dinyatakan bahwa masyarakat hukum adat mempunyai peran penting dalam pengelolaan dan pembangunan lingkungan hidup karena pengetahuan dan praktik tradisional mereka. Oleh karena itu, negara harus mengenal dan mendukung penuh entitas, kebudayaan, dan kepentingan mereka serta memberikan kesempatan berpartisipasi aktif dalam pencapaian pembangunan yang berkelanjutan (sustainable development). ${ }^{45}$ Hasil penting lainnya dari Earth Summit adalah Agenda 21. Dalam Chapter 26 Agenda 21, ditegaskan tentang adanya perlindungan terhadap hak ulayat dari masyarakat hukum adat, sebagai berikut:

"Indigenous people and their communities have an historical relationship with their lands and are generally descendants of the original inhabitants of such lands. In the context of this chapter the term "lands" is understood to include the environment of the areas which the people concerned traditionallyoccupy".

Deklarasi Rio 1992 pada dasarnya menegaskan bahwa setiap negara atau pemerintah berkewajiban menghormati tradisi, pengetahuan, dan peran penduduk asli dalam pengelolaan lingkungan dan pembangunan serta pemeliharaan jati diri, kebudayaan, dan kepentingan mereka.

\section{United Nations Declaration on the Rights of Indigenous Peoples (UNDRIP)}

Perjuangan masyarakat hukum adat mencapai puncaknya, setelah Majelis Umum PBB, melalui pemungutan suara mayoritas (144 negara menyatakan mendukung, 4 negara menolak, 11 negara abstain, dan 30 negara tidak hadir), untuk mengadopsi United Nations Declaration on the Rights of Indigenous Peoples (UNDRIP) pada 13

\footnotetext{
43 Lihat International Labour Organization (ILO), Application of Convention No.169 by Domestic and International Courts in Latin America: A Casebook, ILO Publications, 2009.

44 Sophie Lemaitre, Op.cit., hlm. 153-154.

45 Lihat Prinsip 22 Deklarasi Rio 1992.
} 
September 2007.46 Keadaan masyarakat hukum adat di seluruh dunia yang memprihatinkan menjadi perhatian masyarakat internasional, khususnya setelah Majelis Umum PBB mengadopsi UNDRIP. ${ }^{47}$ Perhatian internasional yang semakin meningkat atas peristiwa penindasan, penundukan, dan upaya untuk peminggiran masyarakat hukum adat, memunculkan upaya-upaya yang positif dan agresif untuk mendorong adanya pengakuan internasional terhadap hak-hak mereka. ${ }^{48}$ Bagi masyarakat hukum adat, pengesahan Deklarasi PBB tentang hak-hak masyarakat hukum adat ini merupakan tonggak yang bersejarah, setelah melalui perjuangan yang panjang untuk memperoleh pengakuan internasional atas hak-hak mereka yang telah dimulai sejak lebih dari 23 tahun di PBB. ${ }^{49}$

Meskipun Majelis Umum PBB telah mengadopsi UNDRIP, perdebatan tentang ruang lingkup hak menentukan nasib sendiri (self-determination) masyarakat hukum adat masih terus berlangsung hingga sekarang. ${ }^{50}$ Dalam Pasal 3 UNDRIP, dinyatakan: "Indigenous peoples have the right to self-determination. By virtue of that right they freely determine their political status and freely pursue their economic, social and cultural development". Berdasarkan Pasal 3 ini, diatur sangat jelas tentang pengakuan hak untuk menentukan nasib sendiri. Hak tersebut termasuk hak dalam bidang politik, hak untuk mengembangkan ekonomi, dan hak untuk pembangunan dalam bidang sosial dan budaya.

Hak untuk menentukan nasib sendiri sudah diterima dalam hukum internasional. ${ }^{51}$ Pada tahun 1996, International Court of Justice (ICJ) dalam Kasus

46 United Nations Declaration on the Rights of Indigenous Peoples, General Assembly Resolution 61/295, Annex U.N. Doc.A/RES/61/295 (September 13, 2007), dikutip dari http://www2.ohchr.org/ english/issues/indigenous/declaration.htm.

47 Muhamad Sayuti dan Rohaida Nurdin, "Economic Dimension of the Right to Self-Ditermination of the Orang Asli: Right to Land and Natural Resources", dalam: The $4^{\text {th }}$ International Graduate Students Conference on Indonesia, "Theme Indigenous Communities and The Projects of Modernity", Proceeding, The Graduate School UGM, 30-31 Oktober 2012, hlm. 392.

$48 \mathrm{Ibid}, \mathrm{hlm} .392$.

49 Perhatian yang cukup serius terhadap hak-hak masyarakat hukum adat, khususnya terkait dengan hak atas tanah, dimulai sejak dibentuknya World Council of Indigenous People (WCIP) pada tahun 1966. Pada tahun 1982 dibentuk Working Group on Indigenous People (WGIP) melalui persetujuan Dewan Sosial dan Ekonomi PBB. Proses pembuatan draf dan pembahasan isi deklarasi ini sudah dimulai tahun 1994 dan Kelompok Kerja Draf Deklarasi baru berhasil menyelesaikan tugasnya serta menyerahkan hasilnya ke Komisi PBB tentang HAM pada bulan Februari 2006. Lihat juga Lembar Fakta Hak Asasi Manusia (HAM), Edisi III yang diterbitkan oleh Komisi Nasional Hak Asasi Manusia.

50 Muhamad Sayuti dan Rohaida Nurdin, "Economic Dimension of the Right to Self-Ditermination of the Orang Asli: Right to Land and Natural Resources", dalam: The $4^{\text {th }}$ International Graduate Students Conference on Indonesia, "Theme Indigenous Communities and "The Projects of Modernity", Proceeding, The Graduate School UGM, 3031 Oktober 2012, hlm. 391.

51 Rohaida Nordin, Muhammad Sayuti dan Matthew Albert Witbrodt, "Indigenous Peoples in Asia: Indigenousness and Self-determination", Makalah, dipresentasikan dalam The $9^{\text {th }}$ Annual Asli Conference 2012, Singapura, tanggal 31 Mei-1 Juni 2012, hlm. 3. Hak untuk menentukan nasib sendiri (Right to Self-determination) juga diatur 
Portugal v. Australia (East Timor Case), mendefinisikan hak untuk menentukan nasib sendiri sebagai "erga omnes". Anaya menyatakan bahwa hak untuk menentukan nasib sendiri ditetapkan sebagai bagian dari jus cogens dan secara umum diterima dalam hukum internasional. ${ }^{52}$ Dalam kaitannya dengan masyarakat hukum adat, hak untuk menentukan nasib sendiri merupakan representasi dari kebebasan untuk membuat keputusan terkait dengan hal-hal yang berpengaruh terhadap mereka, untuk hidup sesuai dengan cara hidup mereka yang tradisional, nilai dan keyakinan mereka, dan mendapatkan perlakuan yang sama dalam negara. ${ }^{53}$

Hak untuk menentukan nasib sendiri juga sangat berkaitan dengan pemanfaatan sumber daya alam. Pada UNDRIP diatur dengan lebih jelas ketentuan tentang hak-hak masyarakat hukum adat terhadap sumber daya alam. Pasal 26 ayat (2) UNDRIP secara khusus telah menetapkan bahwa: "Indigenous peoples have the right to own, use, develop and control the lands, territories and resources that they possess by reason of traditional ownership or other traditional occupation or use, as well as those which they have otherwise acquired". Masyarakat hukum adat mempunyai hak untuk memiliki dan mengelola tanah dan sumber daya alam dengan alasan kepemilikan tradisional. Dalam kasus Delgamuukw v. British Colombia, Ketua Mahkamah Agung memutuskan bahwa label indigeneous adalah sui generis, ${ }^{54}$ yaitu label tersebut diperoleh atas dasar kehidupan dan penghidupan mereka di wilayah tersebut sejak lama. Di samping itu, dalam kasus The Mayagna (Sumo) Awas Tingi Community v. Nicaragua, the Inter-American Court of Human Right diakui hak atas harta dari masyarakat hukum adat dengan memperhatikan instrumen internasional, seperti Pasal 14 ayat (2) Konvensi ILO $169^{55}$ dan perjanjian internasional tentang Hak Asasi Manusia Amerika Serikat.

dalam Pasal 1 the International Covenant on Civil and Political Right (ICCPR), dan ketentuan yang sama juga terdapat dalam Pasal 1 the International Covenant on Social, Economic, and Cultural Rights (ICSECR) yang mengakui hak untuk menentukan nasib sendiri bagi semua orang.

52 Muhamad Sayuti dan Rohaida Nurdin, "Economic Dimension of the Right to Self-Ditermination of the Orang Asli......., Op.cit.,hlm. 396.

53 Anaya JS, Indigenous Peoples in International Law, New York: Oxford University Press, 2004, hlm. 97.

54 Muhamad Sayuti dan Rohaida Nurdin, "Economic Dimension of the Right to Self-Ditermination of the Orang Asli.....", Op.cit., hlm. 398.

55 Pasal 14 Konvensi ILO 169 menyatakan:

(1) The rights of ownership and possession of the peoples concerned over the lands which they traditionally occupy shall be recognised. In addition, measures shall be taken in appropriate cases to safeguard the right of the peoples concerned to use lands not exclusively occupied by them, but to which they have traditionally had access for their subsistence and traditional activities. Particular attention shall be paid to the situation of nomadic peoples and shifting cultivators in this respect;

(2) Governments shall take steps as necessary to identify the lands which the peoples concerned traditionally occupy, and to guarantee effective protection of their rights of ownership and possession;

(3) Adequate procedures shall be established within the national legal system to resolve land claims by the peoples concerned. 
Sebagaimana Konvensi ILO 169, UNDRIP kembali menegaskan kewajiban negara melaksanakan prinsip the free, prior and informed consent dari masyarakat adat sebelum menyetujui dan melaksanakan proyek yang dapat memengaruhi tanah mereka. Dalam Pasal 32 ayat (2) deklarasi ini dinyatakan sebagai berikut:

"States shall consult and cooperate in good faith with the indigenous peoples concerned through their own representative institutions in order to obtain their free and informed consent prior to the approval of any project affecting their lands or territories and other resources, particularly in connection with the development, utilization or exploitation of mineral, water or other resources".

Selain itu, masyarakat adat memiliki hak mendapatkan restitusi atas tanah mereka dan kompensasi jika restitusi tidak memungkinkan. ${ }^{56}$ Uraian tersebut menunjukkan bahwa hukum internasional mengakui hak masyarakat adat untuk menentukan nasib sendiri. Dalam bidang tanah dan sumber daya alam, hak tersebut diatur dengan jelas dalam UNDRIP meskipun masih berupa instrument yang soft law, yaitu tidak mengikat secara hukum. Paling tidak, hal ini harus ditafsirkan sebagai sebuah standar yang baik dan merupakan pengakuan atas semua hak masyarakat hukum adat di seluruh dunia untuk dapat berdiri sejajar dengan masyarakat yang lainnya.

\section{Penutup}

Entitas masyarakat adat semakin diakui oleh banyak negara. Setiap pemerintah harus menghormati kebudayaan dan nilai-nilai yang ada di dalam masyarakat adat. UNDRIP merupakan instrumen internasional utama yang mengakui dan menjunjung tinggi hak-hak masyarakat adat. Berdasarkan deklarasi ini, negara memiliki kewajiban menghormati dan memenuhi hak-hak masyarakat adat tersebut. Deklarasi ini juga mengakui the right to Free, Prior and Informed Consent sebagai prasyarat dalam memutuskan kegiatan yang memengaruhi wilayah dan tanah masyarakat adat atau undang-undang lain yang dapat memengaruhi pemenuhan hak-hak masyarakat adat.

UNDRIP memberikan perlindungan yang kuat terhadap hak masyarakat adat atas sumber daya alam. Akan tetapi, sebagai soft law tentu saja masih merupakan instrumen yang tidak mengikat secara hukum. Meskipun demikian, deklarasi ini tetap memiliki pengaruh yang signifikan dan dapat menjadi langkah awal menuju penerapan instrumen yang mengikat di masa depan atau dapat berkembang menjadi customary international law. Di samping UNDRIP, Konvensi ILO 169 juga mengatur 
berbagai hak dan perlindungan bagi masyarakat adat, dengan penekanan khusus pada hak masyarakat adat untuk berkonsultasi dan berpartisipasi dalam membuat keputusan tentang kegiatan yang mempengaruhi mereka.

Indonesia merupakan salah satu negara anggota PBB yang secara konsisten memberikan suara mendukung dan ikut menjadi penandatangan dalam pengesahan UNDRIP. Dengan demikian, Indonesia memiliki kewajiban untuk menghormati (to respect), melindungi (to protect), dan memenuhi (to fulfill) hak-hak masyarakat hukum adat yang telah dijamin oleh deklarasi ini. UUD 1945 baru sampai pada tahap memberikan pengakuan yang deklaratif terhadap kesatuan masyarakat hukum adat beserta hak-hak tradisionalnya (hak ulayat) yang diikuti dengan persyaratan merupakan keadaan yang bertentangan dengan tujuan pengakuan dan penghormatan itu sendiri. Adanya persyaratan yang bersifat membatasi itu memberikan ruang kepada pemerintah untuk menafsirkan sendiri secara berbeda dengan kepentingan masyarakat hukum adat. Faktanya adalah persyaratan itu kemudian diikuti dan dikembangkan dalam beberapa peraturan yang mengatur tentang kesatuan masyarakat hukum adat dan hak ulayat dalam sejumlah undangundang di bidang sumber daya alam. Pengakuan tersebut belum sampai pada tindakan hukum to protect dan to fulfill hak masyarakat adat atas hak ulayat. Sehingga mekanisme penegakan hukum atas pelanggaran yang terjadi terhadap hak ulayat juga belum dibuat.

Pemerintah, baik pemerintah pusat, maupun pemerintah daerah harus dapat memastikan bahwa mereka melindungi hak-hak masyarakat adat dan menghilangkan diskriminasi terhadap masyarakat adat, serta melaksanakan undang-undang tentang perlindungan masyarakat adat secara efektif. Harus ada pengakuan bahwa pengutamaan hak-hak masyarakat adat atas tanah dan sumber daya alam yang telah mereka kuasai dan pelihara secara turun temurun sejak zaman dahulu. Ketidakmampuan masyarakat adat untuk mengikuti proses sertifikasi tanah secara modern, tidak boleh dijadikan sebagai alasan untuk perampasan penguasaan hak mereka untuk kepentingan apapun.

\section{Daftar Pustaka}

\section{Buku}

Anaya J.S., Indigenous Peoples in International Law, Oxford University Press, New York, 2004.

Bushar Muhammad, Asas-Asas Hukum Adat Suatu Pengantar, Pradnya Paramita, Jakarta, 1976. 
Darji Darmodiharjo dan Shidarta, Pokok-Pokok Filsafat Hukum Apa dan Bagaimana Filsafat Hukum Indonesia, Gramedia, Jakarta, 2006.

Dewan Kehutanan Nasional dan UN-REDD Programme Indonesia, Rekomendasi Kebijakan: Instrumen Free, Prior Informed Consent (FPIC) Bagi Masyarakat Adat dan/atau Masyarakat Lokal yang akan Terkena Dampak dalam Aktivitas REDD+ di Indonesia, Jakarta, 2011.

Hans Kelsen, General Theory of Law and State, (Alih Bahasa Somarno), Rimdi Press, Jakarta, 1973.

Hazairin, Tujuh Serangkai Tentang Hukum, Tinta Mas Indonesia, Jakarta.

Hilman Hadikusumah, Pokok-Pokok Pengertian Hukum Adat, Alumni, Bandung, 1980.

H. L. A. Hart, Konsep Hukum The Concept Of Law, Nusa Media, Bandung, 2009.

Ida Nurlinda, Prinsip-Prinsip Pembaharuan Agraria: Perspektif Hukum, Rajawali Pers, Jakarta, 2009.

I Nyoman Nurjaya, Pengelolaan Sumber Daya Alam dalam Perspektif Antropologi Hukum, Prestasi Pustaka, Jakarta, 2008.

International Labour Organization (ILO), Application of Convention No.169 by Domestic and International Courts in Latin America: A Casebook, 2009.

Mahfud MD, Pergulatan Politik dan Hukum di Indonesia, Gamamedia, Yogyakarta, 1999.

Mitch, Bruce, B. Setiawan dan Dwita Hadi Rahmi, Pengelolaan Sumberdaya dan Lingkungan, Gadjah Mada University Press, Yogyakarta, 2000.

Rafael Edy Bosko, Hak-Hak Masyarakat Adat dalam Konteks Pengelolaan Sumber Daya Alam, Elsam, Jakarta, 2006.

Rawls, John, A Theory of Justice, Harvard University Press, Cambridge, 1971.

Sandra Moniaga, Hak-hak Masyarakat Adat dan Masalah serta Kelestarian Lingkungan Hidup di Indonesia, HuMa, Jakarta, 2005.

Schrijver, Nico, Sovereignty over Natural Resources: Balancing Rights and Duties, Cambridge University Press, Cambridge, 1997.

Teubner, Gunther (ed.), Dilemma of law in the Welfare State, Walter de Gruyter, New York, 1988.

United Nations Development Programme, Human Development Report 2011 Sustainability and Equity: A Better Future for All, Palgrave Macmillan, New York, 2011.

World Bank, Indonesia Environment and Development: Challenges for the Future, 1994. 


\section{Dokumen Lain}

Achmad Sodiki, "Kebijakan Sumber Daya Alam dan Implikasi Juridisnya Pasca TAP MPR No.IX/MPR/2001 dan Kepres No 34 Tahun 2003". Makalah, disampaikan dalam Seminar Nasional "Eksistensi dan Kewenangan BPN Pasca Keppres No. 34 Tahun 2003", Malang.

, "Masalah Konflik Peraturan Perundang-undangan dan Konflik di Lapangan Agraria dan Usulan Penanganannya (Mencari Format Penanganan Konflik Agraria dalam Rangka Implementasi Ketetapan MPR No.IX/MPR/2001)". Makalah, disampaikan sebagai Penanggap Utama dalam Seminar Nasional Strategi Pelaksanaan Pembaharuan Agraria, 26 September 2002, Jakarta, 2002. , "Penataan Kepemilikan Hak atas Tanah di Daerah Perkebunan Kabupaten Malang (Studi tentang Dinamika Hukum)". Disertasi. Program Pascasarjana Universitas Airlangga, Surabaya, 1994.

Corntassel, Jeff, dan Cheryl Bryce, "Practicing Sustainable Self-Determination: Indigenous Approaches to Cultural Restoration and Revitalization", Brown Journal of World Affairs, Volume XVIII, Issue II, Spring/Summer 2012, hIm. 151.

Farida Patittingi, "Peranan Hukum Adat dalam Pembinaan Hukum Nasional dalam Era Globalisasi", Majalah IImu Hukum Amanna Gappa, Volume 11 Nomor 13, Januari-Maret 2003, Fakultas Hukum Universitas Hasanudin, Makassar, 2003.

Hasnati, "Pertautan Kekuasaan Politik dan Negara Hukum", Jurnal Hukum Republica, Volume 3 Nomor 1, Tahun 2003, Fakultas Hukum Universitas Lancang Kuning, Pekanbaru, 2003.

Husen Alting, "Penguasaan Tanah Masyarakat Hukum Adat (Suatu Kajian Terhadap Masyarakat Hukum Adat Ternate)", Jurnal Dinamika Hukum, Volume 11 Nomor 1, Januari 2011.

Jawahir Thontowi, "Komunitas Lokal dalam Perspektif HAM dan Hukum Nasional", Jurnal Hukum, Volume 57, Juli 2005.

Jufrina Rizal, "Perkembangan Hukum Adat sebagai Living Law dalam Masyarakat", Jurnal IImu Hukum Amanna Gappa, Volume 16 Nomor 1, Maret 2008, Fakultas Hukum Universitas Hasanudin, Makassar, 2008.

Lemaitre, Sophie, "Indigenous Peoples' Land Rights and REDD: A Case Study", Review of European Community \& International Environmental Law (RECIEL) 20 (2) 2011, ISSN 09628797.

Lily Bauw dan Bambang Sugiono, "Pengaturan Hak Masyarakat Hukum Adat di Papua dalam Pemanfaatan Sumberdaya Alam", Jurnal Konstitusi, Volume I Nomor 1, Juni 2009, MKRI, Jakarta, 2009. 
Masyhud Asyhari, "Pemberdayaan Hak-Hak Rakyat atas Tanah", Jurnal Hukum lus Quialustum, Volume 13 Nomor 7, April 2000.

Muchsin, "Kedudukan Tanah Ulayat dalam Sistem Hukum Tanah Nasional", Varia Peradilan, XXI (245) April 2006, Ikahi, Jakarta, 2006.

Muhamad Sayuti dan Rohaida Nurdin, "Economic Dimension of the Right to SelfDetermination of the Orang Asli: Right to Land and Natural Resources", dalam The $4^{\text {th }}$ International Graduate Students Conference on Indonesia, Theme Indigenous Communities and "The Projects of Modernity", Proceeding, The Graduate School UGM, 30-31 Oktober 2012, Yogyakarta, 2012.

Ni'matul Huda, "Beberapa Kendala dalam Penyelesaian Status Hukum Tanah Bekas Swapraja di Daerah Istimewa Yogyakarta", Jurnal Hukum, Volume 13 Nomor 7 April 2000, Fakultas Hukum UN, Yogyakarta, 2000.

Rachmad Syafa'at, "Kearifan Lokal dalam Masyarakat Adat di Indonesia", Jurnal Publica, Volume 4 Nomor 1, Januari 2008, FISIP UMM, Malang, 2008.

Rohaida Nordin, Muhammad Sayutidan Matthew Albert Witbrodt, "Indigenous Peoples in Asia: Indigenousness and Self-determination", Makalah, dipresentasikan dalamThe $9^{\text {th }}$ Annual Asli Conference 2012, Singapura, tanggal 31 Mei-1 Juni 2012.

Steny, Bernard, "Pluralisme Hukum: Antara Perda Pengakuan Masyarakat Adat dan Otonomi Hukum Lokal", Jurnal Pembaruan Desa dan Agraria, Volume 3 Nomor 3 , Tahun 2006.

Teddy Anggoro, "Kajian Hukum Masyarakat Hukum Adat dan HAM dalam Lingkup Negara Kesatuan Republik Indonesia", Jurnal Hukum dan Pembangunan, Volume 36 Nomor 4, Oktober-Desember 2006, Fakultas Hukum Universitas Indonesia, Jakarta, 2006. 